An RNA fraction in chromatin of L-929 cells associated with DNA

John J. Monahan and Ross H.Hall

Department of Blochemistry, McMaster University Medical Centre, Hamilton, Ontario, Canada L8S 4J9

Received 6 August 1974

ABSTRACT

The DNA of I-929 cell nuclei was examined for the presence of an RNA fraction hybridized to the DNA that could possibly serve a role in gene regulation. A low molecular weight ( $4.5 \mathrm{~S})$ RNA fraction was observed as an RNA-DNA complex in chromatin preparations subfractionated on a $\mathrm{Cs}_{2} \mathrm{SO}_{4}$ density gradient. This RNA does not appear to be covalently attached to the DNA. Neither does it appear to be attached to the DNA via a protein component. The RNA is resistant to ribonuclease $H$ but is slowly attached by ribonuclease $A+T I$. A role for, as well as the nature of the attachment of this RNA to DNA is suggested.

\title{
INTRODUCTION
}

Recent progress in the study of the eukaryotic cell chromosome has led to a number of models to explain how gene regulation in eukaryotic cells at the transcriptional level may take place. I In a number of cases it has been suggested that an RNA component becomes associated with the DNA of chromatin thereby "activating" a particular gene or set of genes.1-4 Experimental evidence for such an RNA fraction has been sadly lacking. Much interest has centered around one RNA fraction isolated from chromatin called "chromosomal RNA" which was suggested to be involved in gene regulation. 5 The identity of this RNA has been disputed by some investigators. 6,7 In a search for a hypothetical gene "activator RNA" used in a model we have recently prepared for gene regulation in eukaryotes, 1 we have chosen to utilize the idea that such an RNA may recognize a specific base sequence on the DNA and in doing so would probably be (at least temporarily) hybridized to the DNA. Clearly, there are many other possibilities, for example, 
activator RNA's could bind to the protein components of the chromosome displacing them from the DNA thus allowing the polymerase to transcribe that region of DNA. Our hypothetical activator RNA might possibly hybridize with sequences of DNA in either local regions of double strand separation 32,33 or with double stranded DNA as a triple 34 or a four stranded structure. $8,9,39$

Because there are a number of RNA components in purified chromatin preparations that are not hybridized to the DNA, 10 it was necessary to develop a procedure that would carefully distinguish a true DNA-RNA hybrid structure from other probably ionic interactions. We have used as the basis of our experimental procedure the characteristic buoyant densities of free RNA, DNA, and a DNA-RNA hybrid in $\mathrm{Cs}_{2} \mathrm{SO}_{4}$ and $\mathrm{CsCl}$ to isolate an RNA fraction hybridized to the DNA. This procedure is described in detail elsewhere. 11 METHODS

Cells: Mouse L-929 cells were originally obtained from Microbiological Associates, Bethesda, Maryland. Addition of radioactive precursors and collection of cells was carried out as described previously.12 Unless stated otherwise, about $5 \times 10^{7}$ cells were treated with $10 \mathrm{mCi}$ carrier free ${ }^{32} \mathrm{P}_{3} \mathrm{H}_{3} \mathrm{PO}_{4}$ for 4 hours for each experiment.

Polyacrylamide Gel Electrophoresis: The DNAA-RNA fraction was analyzed as described previous $1 y^{10}$ on a $12.5 \%$ acrylamide, $0.375 \% \mathrm{~N}, \mathrm{~N}^{\prime}$-methylenebisacrylamide gel containing $0.04 \mathrm{M}$ Tris-citric acid $\mathrm{pH} 8.0,0.1 \%$ SDS.

Column Chromatography: The chromatin DNA and DNAA-RNA fractions were separated on a $1.0 \mathrm{~cm} \times 20 \mathrm{~cm}$ high nitrocellulose column as described by Boezi and Armstrong ${ }^{13}$ except that the denatured DNA fraction was eluted with $0.01 \mathrm{M}$ Tris $\mathrm{pH} 7.3,0.5 \%$ sodium sarcosyl.

Base Composition of RNA: The 32P-RNA fractions were hydrolyzed with 10\% aqueous piperidine as described previously. 22 The nucleotides were separated by two-dimensional chromatography on cellulose plates (Eastman 6065 cellulose, $20 \mathrm{~cm} \times 20 \mathrm{~cm}$ ). The solvent systems were isobutyric acid - 
$0.5 \mathrm{M} \mathrm{NH}_{3}$, 5:3 by volume; and isopropanol - concentrated HCl-water, 70:15:15 by volume. The location of each nucleotide was determined by exposing the chromatogram to a Kodak $\mathrm{RP} / \mathrm{R} \mathrm{X}-\mathrm{OMAT}$ rapid-processing $\mathrm{X}$-ray film. Exposure time ranged from 1 to 4 days.

Chemical Analysis: DNA was assayed by the method of Burton 14 using calf thymus DNA (Sigma) as a standard. RNA was assayed by the method of Webb $^{15}$ using yeast-soluble RNA (B.D.H. England) as a standard. Protein was assayed by the method of Lowry et al. 16 using bovine serum albumin (Sigma) as a standard. The density of the cesium sulfate cradient was determined as described previouslyl2.

Reagents: Only the purest available chemicals were used. $\mathrm{Cs}_{2} \mathrm{SO}_{4}$ 99.9\% was obtained from Hruden, London, Ontario. RLI was obtained from Searle, Buckinghamshire, England.

Nitrocellulose (nitrocell-S) was obtained from Serva, New York. (53H) uridine $20,000 \mathrm{mCi} / \mathrm{mmol}$, was obtained from Amersham/Searle, Toronto. (32 $\mathrm{P}_{3} \mathrm{HO}_{4}$ carrier free was obtained from New England Nuclear, Montreal.

Preparation of Chromatin: Chromatin was isolated and purified by a modification of a procedure previously described in detail elsewhere. 11 Because we might expect a hypothetical gene activator RNA to reversibly associate with DNA in vivol it is possible that only a small fraction of the RNA will remain associated with the purified chromatin, the remainder being lost in the nucleoplasmic supernatant fraction and during the many steps involved in the isolating of the RNA itself. We have chosen to avoid using buffers of low ionic strength during the preparation of chromatin since this would tend to destabilize a DNA-RNA hybrid structure. Rigorous care was also taken to carefully control the temperature; all procedures being carried out at $4^{\circ} \mathrm{C}$ unless otherwise noted. All glassware was siliconized with Silicad (Clay Adams, Parsippany, N.J.)

Nuclei were isolated from L-929 cells as follows: the cell suspension 
( $5 \times 10^{7}$ cells) was collected by low speed centrifugation and suspended in $10 \mathrm{mls}$ of $0.14 \mathrm{M} \mathrm{NaCl}, 1.5 \mathrm{mM} \mathrm{MgCl} 2,0.001 \mathrm{M} \mathrm{HEPES,} 0.5 \mathrm{mM}$ PMSF, 4 units/ ml RLI, 0.5\% Triton X-114 pH 7.2, The cells were homogenized in a Dounce homogenizer (type $b$ ). The nuclei were collected by centrifugation for 5 minutes at $600 \times \mathrm{g}$. The homogenization and centrifugation was repeated two further times, the last time without any Triton X-114 present. Microscopic examination revealed nuclei free of intact cells and cytoplasmic tags. 11 Due to the $0.14 \mathrm{M} \mathrm{NaCl}$ present in the above buffer we expect that the so-called "nuclear sap" proteins and RNA's are removed from these nuclei.17 Chromatin was then extracted from the nuclei with $1 \mathrm{M} \mathrm{NaCl}$, $2 \mathrm{mM}$ HEPES, $2 \mathrm{mM}$ EDTA, $2 \mathrm{mM}$ 2-ME, $0.5 \mathrm{mM}$ PMSF, 4 units/ml RLI, pH 8.0. The nucleolar and nuclear membrane material were removed by centrifugation at $20,000 \times g$ for 20 minutes. We refer to the material present in the $1 \mathrm{M}$ $\mathrm{NaCl}$ buffer supernatant as chromatin. In fact, it is a mixture of dissociated chromatin components since solutions of such high ionic strength are known to dissociate many chromosomal proteins and nonDNA-RNA hybridized RNA 11,18 from chromatin. However, because any chromatin RNA components that are hybridized to DNA in vivo will remain attached to DNA (indeed high salt will stabilize such on attachment) we can, in this case, use this procedure to extract chromatin from the washed nuclei without danger of losing these structures.

\section{Fractionation of Chromatin}

We have shown previously ${ }^{11}$ that by isopycnic gradient centrifugation in a $53 \% \mathrm{~W} / \mathrm{V} \mathrm{Cs}_{2} \mathrm{SO}_{4}$ solution containing $10 \% \mathrm{DMSO}$, it is possible to separate the free RNA, DNA and protein components of chromatin from each other with little cross contamination. To the chromatin supernatant obtained after the $20,000 \times$ g centrifugation is added $2.65 \mathrm{gms} \mathrm{Cs}_{2} \mathrm{SO}_{4}, 0.04 \mathrm{gms}$ sodium sarcosyl and $0.5 \mathrm{mls}$ DMSO. The final volume is adjusted to $5 \mathrm{mls}$ with the $1 \mathrm{M} \mathrm{NaCl}$ buffer. After 56 hours centrifugation in an ICE SB-283 rotor 
at $30,000 \mathrm{RPM}$ at $5^{\circ} \mathrm{C}$ the $32 \mathrm{P} \mathrm{CPM}$ profile shown in Figure 1 was obtained.

The "free RNA" and protein fractions of chromatin have been analyzed and described in detail elsewhere. ${ }^{10}$ If the DNA peak in Figure 1 (tubes 18-25) is dialyzed against $0.1 \mathrm{M}$ sodium acetate $\mathrm{pH} 5.5$, precipitated with ethanol and an aliquot of the precipitate is treated with $0.3 \mathrm{M} \mathrm{NaOH}$ for 18 hours at $37^{\circ} \mathrm{C}$, it is repeatedly found that about $2-3 \%$ of the $32 \mathrm{P}$ material is labeled RNA. This RNA which we shall call DNA associated RNA (DNAA-RNA) is, we believed, somehow hybridized to the DNA in vivo. The remainder of this paper is concerned with tests for this hypothesis. RESULTS

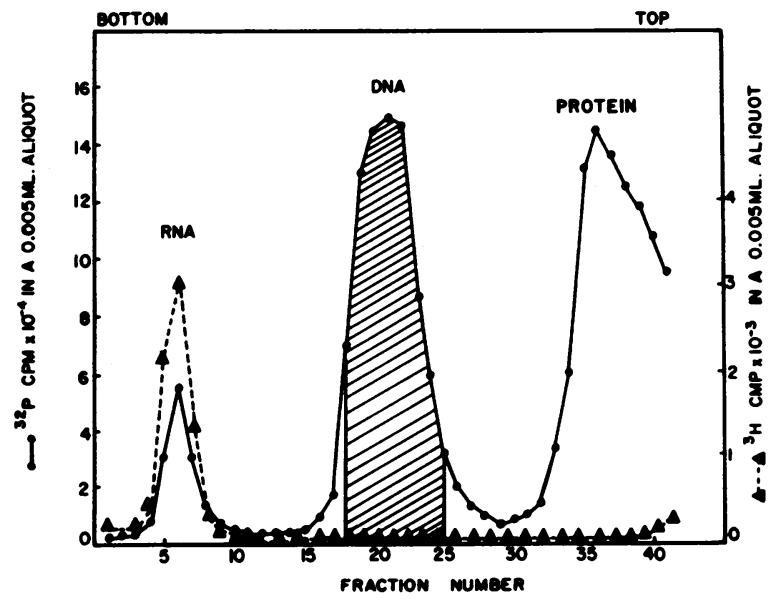

Fig. 1: Isopycnic banding of dissociated chromatin components in a $\mathrm{Cs}_{2} \mathrm{SO}_{4}$ gradient $(\longrightarrow)$, 32 $\mathrm{P}$ labeled material. $(\Delta--\rightarrow)$, $3_{\mathrm{H}} 28 \mathrm{~S}$ and $4 \mathrm{~S}$ RNA added to the chromatin preparation before centrifugation. 6 drop fractions were collected from the bottom of the tube.

To establish that the alkali ${ }^{32} \mathrm{P}$ labeled material associated with DNA is in fact RNA, we have hydrolyzed an aliquot of the $\mathrm{Cs}_{2} \mathrm{SO}_{4}$ gradient DNA fraction, and analyzed the products by two dimensional chromatography on TLC cellulose plates. ${ }^{12}$ Autoradiography with X-ray film reveals that most of the ${ }^{32} \mathrm{P}$ remains at the origin. This is $32 \mathrm{P}$ label incorporated into DNA. Four other distinct spots can be seen (Fig. 2) cochromatographing with Gp, Cp, Up, and Ap. The base composition of the DNAA-RNA was found to be $28.3 \% \mathrm{G}, 22.2 \% \mathrm{C}, 24.4 \% \mathrm{U}, 25.1 \% \mathrm{~A}$. No other nucleotides could be seen. 
It is important to rule out the possibility that the DNAA-RNA in the $\mathrm{Cs}_{2} \mathrm{SO}_{4}$ DNA fraction was not simply due to peak overlap of the free RNA peak with the DNA peak in the same gradient. To eliminate this possibility, the DNA fraction of a $\mathrm{Cs}_{2} \mathrm{SO}_{4}$ gradient was collected, readjusted to $5 \mathrm{mls}$ with more $(54 \% \mathrm{~W} / \mathrm{V}) \mathrm{Cs}_{2} \mathrm{SO}_{4} /$ sodium sarcosyl/DMSO buffer and recentrifuged as described in the methods section. There was no loss of DNAA-RNA in the DNA fraction. The DNAA-RNA is, therefore, clearly not a free single or double stranded RNA since these band at much higher densities on such gradients. 19 The DNAA-RNA must be in some way associated with the DNA.

Treatment of the DNA fraction obtained from a $\mathrm{Cs}_{2} \mathrm{SO}_{4}$ gradient similar to that shown in Figure 1 with proteinase $K$ did not liberate (Table 1 ) the DNAA-RNA free from the DNA in a recentrifugation of this DNA on a second $\mathrm{Cs}_{2} \mathrm{SO}_{4}$ gradient. It would appear, therefore, that the DNAA-RNA is not linked to the DNA by a very small amount of residual protein attached to the DNA.

\begin{tabular}{|lcccc|}
\hline \multicolumn{4}{|c|}{ Table $\mathrm{I}$. } & Proteinase $\mathrm{K}$ treatment of DNAA-RNA \\
\hline Species & $32 \mathrm{P}$ in DNA & $32 \mathrm{P}$ in DNAA-RNA & $\%$ 32p in DNAA-RNA \\
\hline $\begin{array}{l}\text { DNA from first } \\
\mathrm{Cs} \mathrm{SO}_{4} \text { gradient }\end{array}$ & $13.651 \times 10^{6} \mathrm{CPM}$ & $0.381 \times 10^{6} \mathrm{CPM}$ & $2.7 \%$ \\
DNA after treat- $12.285 \times 10^{6} \mathrm{CPM}$ & $0.296 \times 10^{6} \mathrm{CPM}$ & $2.4 \%$ \\
$\begin{array}{l}\text { ment with proteinase } \\
\text { K and a second } \mathrm{Cs}_{2} \mathrm{SO} 4 \\
\text { gradient }\end{array}$ & & & \\
\hline
\end{tabular}

The DNA was incubated in a volume of $2 \mathrm{mls}$ with $50 \mu \mathrm{g}$ of proteinase $\mathrm{K}$ in $0.2 \mathrm{M} \mathrm{NaCl}, 0.01$ Tris, 0.001 EDTA, $0.1 \% \mathrm{SDS} \mathrm{pH} 8.0$ at $37^{\circ} \mathrm{C}$ for 20 minutes. 
It is clearly important to establish that this DNAA-RNA does not become attached to the DNA by some artifact of the isolation procedure. While Williams and Vinograd ${ }^{19}$ have shown that such $\mathrm{Cs}_{2} \mathrm{SO}_{4}$ gradients containing 10\% DMSO make a nonspecific aggregation of RNA to DNA unlikely, we have looked into this possibility. Figure 1 shows that $3 \mathrm{H}$ uridine labeled purified 28S rRNA and 4S tRNA from L cells added to the $32 \mathrm{P}_{-} \mathrm{H}_{3} \mathrm{PO}_{4}$ labeled chromatin preparation in the $1 \mathrm{M} \mathrm{NaCl}$ isolation buffer did not associate with the DNA band but instead banded with the free RNA. We have repeated this with unlabeled chromatin preparations where even $0.1 \%$ of "free 3H labeled RNA" associated with DNA would have been detected (unpublished observations). No such association was ever observed.

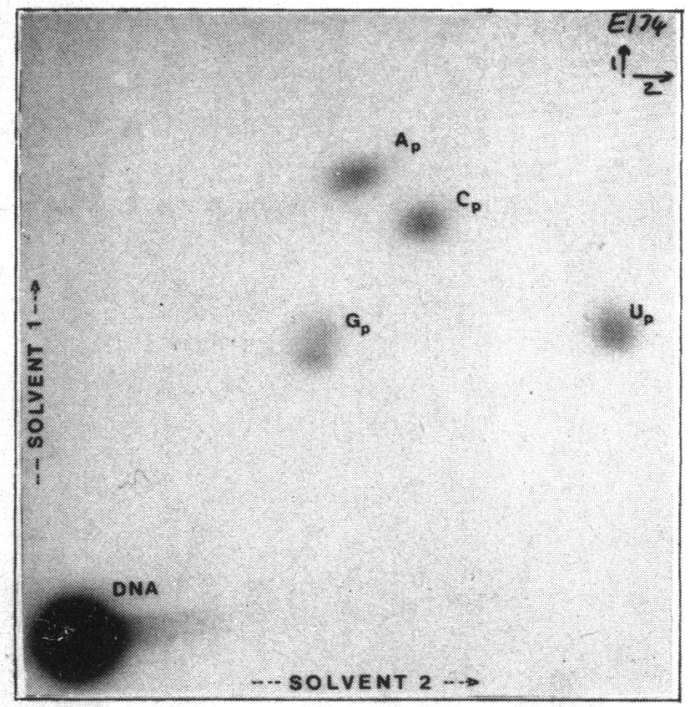

Fig. 2: Two dimensional chromatography on cellulose of the hydrolyzed DNAA-RNA products present in the DNA fraction of Figure 1. 
We have also substituted $\mathrm{Cs}_{2} \mathrm{SO}_{4}$ with $\mathrm{CsCl}$ to isopycnically band the nuclear DNA. This procedure is essentially that described by Flam 20 to prepare nuclear DNA. Since it is a convenient alternative procedure to obtain our DNAA-RNA we shall describe the procedure briefly. To the washed nuclear pellet from $5 \times 10^{7}$ cells was added $6.4 \mathrm{gms}$ of $\mathrm{CsCl}, 40 \mathrm{mgs}$ of sodium sarcosyl and $5 \mathrm{mls}$ of $0.01 \mathrm{M}$ Tris, $0.001 \mathrm{M} \mathrm{EDTA}, \mathrm{pH} \mathrm{7.4}$. The order of the above additions insures a high ionic strength during lysis of the nuclei. After homogenization in a Dounce homogenizer the solution is centrifuged at $10,000 \times \mathrm{g}$ for 10 minutes. The solution below the protein skin is removed, the density is adjusted to $1.71 \mathrm{gms} / \mathrm{cms}^{2}$ and centrifuged in an IEC A 321 rotor for 24 hours at 45,000 RPM and then 24 hours at 35,000 RPM. Figure 3 shows the 32P CPM profile obtained when 8 drop

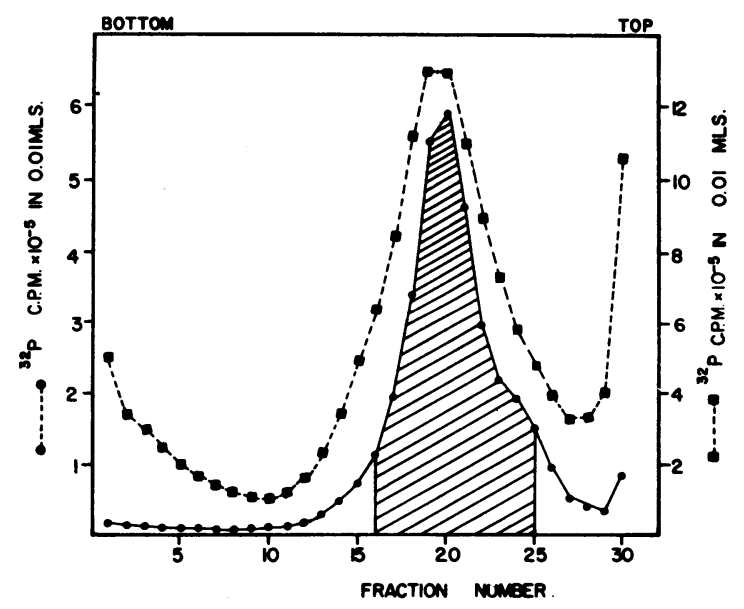

Fig. 3: Isopycnic banding of $\mathrm{L}$ cell DNA in a $\mathrm{CsCl}$ gradient. ( $-\mathbf{-}$ ), 32P labeled material in first centrifugation. $(\longrightarrow)$, 32P labeled material in the second centrifugation obtained from the DNA peak of the first centrifugation. 
fractions are collected from the bottom of the tube. It is usually necessary to pool the DNA fraction (tubes 16-25) to make the volume up to 5.61 mls with buffer and $\mathrm{CsCl}$ to a density of $\rho=1.71$ and recentrifuge as described above a second time, in order to obtain a DNA preparation completely free of protein, and RNA that is not attached to the DNA. In some cases the DNA was sheared by two passes through a 26 gauge needle 21 before the second $\mathrm{CsCl}$ centrifugation. When $5 \times 10^{7}$ cells were labeled with $10 \mathrm{mCi}$ of ${ }^{32} \mathrm{P}_{-} \mathrm{H}_{3} \mathrm{PO}_{4}$ for 4 hours and the DNA was isolated as described above, of the $46.1 \times 10^{6} \mathrm{CPM}$ in the DNA fraction, $9.6 \times 10^{5}$ was alkali labile.

Having established that there is an RNA fraction associated with all such DNA preparations we have initiated an analysis of the nature of the attachment of the DNAA-RNA to the DNA.

A covalently linked RNA-DNA complex has been reported in a wide variety of systems; $\underline{E}$. coli, 22 slime mold, 23 and cultured Ehrlich ascites cell. 24 It has been suggested that these complexes play a role in the initiation of DNA synthesis in vivo. ${ }^{22-24}$ However, recently the existance of this RNA-DNA complex has been questioned. Berger and Huang 25 have failed to isolate such a complex from mouse myeloma cells. Probst et al. 26 suggest that such structures may be an artifact of the procedure used to isolate such RNA-DNA complexes. Is our DNA-RNA covalently linked to DNA?

The DNA fraction from the $\mathrm{Cs}_{2} \mathrm{SO}_{4}$ gradient in Figure 1, dialyzed and precipitated as described above, was denatured with $99 \%$ formamide ( $0.2 \mathrm{mls}$ ) at $37^{\circ} \mathrm{C}$ for 30 minutes. The solution was quickly diluted 20-fold with $0.5 \mathrm{M} \mathrm{KCl}, 0.01 \mathrm{M}$ Tris-HCl, $\mathrm{pH} 7.3$ and cooled in a methanol-ice bath. The DNAA-RNA and denatured chromatin DNA were separated on a $1.0 \mathrm{~cm} \mathrm{x} 20 \mathrm{~cm}$ high nitrocellulose column (Fig. 4). The DNAA-RNA (and about 1-2\% of the DNA) did not bind to the column. It was collected in tubes 3 to 7 , and precipitated with ethanol using $\underline{E}$. coli tRNA carrier. Last traces of the DNA in the DNAA-RNA fraction were removed with a second cycle of denaturing the DNA in 
formamide, and a second nitrocellulose column as described above. All the 32P labeled material in the DNAA-RNA fraction was hydrolyzed with $0.3 \mathrm{M} \mathrm{NaOH}$ at $37^{\circ} \mathrm{C}$ for 18 hours. Such a DNAA-RNA was therefore not covalently linked to DNA.

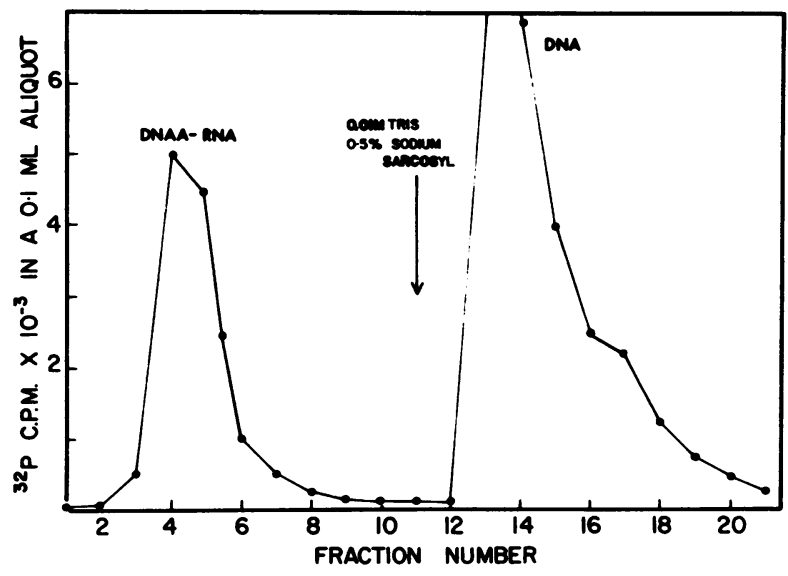

Fig. 4: Elution profile of 4 hour $32 \mathrm{P}_{-} \mathrm{H}_{3} \mathrm{PO}_{4}$ labeled L-cell chromatin DNAA-RNA and denatured DNA from a $1.0 \mathrm{~cm} \times 20 \mathrm{~cm}$ high nitrocellulose column. The DNAA-RNA was eluted with $0.5 \mathrm{M}$ $\mathrm{KCl}, 0.01 \mathrm{M}$ Tris-HCl, $\mathrm{pH} 7.3$. The denatured DNA was eluted with $0.01 \mathrm{M}$ Tris- $\mathrm{HCl}, \mathrm{pH} 7.3,0.5 \%$ sodium sarcosyl.

We have analyzed the DNAA-RNA fraction obtained from a nitrocellulose as described above by polyacrylamide gel electrophoresis using a $12.5 \%$ acrylamide gel (Fig. 5). The DNAA-RNA appears to be of low molecular weight ( $4.5 S$ ). 


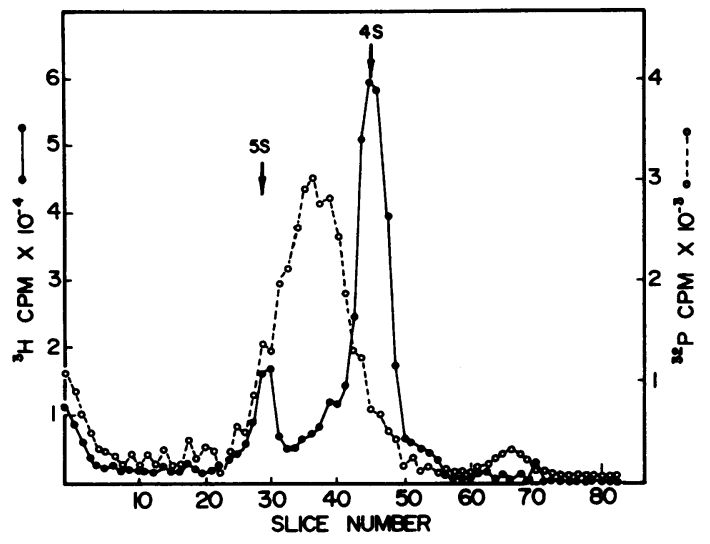

Fig. 5: $12.5 \%$ polyacrylamide gel electrophoresis (2 mm slices) of I-cell DNAA-RNA. (0- - -0) 32P CPM of DNAA-RNA, ( $\longrightarrow$ )

$3_{\mathrm{H}} \mathrm{CPM}$ of $4 \mathrm{~S}$ and $5 \mathrm{~S}$ RNA markers.

Other differences have been seen between the DNAA-RNA described here, and those of covalently bound RNA-DNA complexes involved in DNA syntheses. For example, the synthesis of DNAA-RNA does not appear to be dependent upon DNA synthesis. If $5 \times 10^{6}$ cells in $100 \mathrm{mls}$ of medium are preincubated with $0.5 \mathrm{mM}$ hydroxylurea for 30 minutes before addition of $5 \mathrm{mCi}$ of $32 \mathrm{P}-\mathrm{H}_{3} \mathrm{PO}_{4}$ and this concentration of hydroxylurea is maintained throughout the labeling period ( 4 hours). We find that there is a $99.9 \%$ reduction of ${ }^{32} \mathrm{P}_{-} \mathrm{H}_{3} \mathrm{PO}_{4}$ into DNA compared with only a $10 \%$ reduction of $32 \mathrm{P}^{-\mathrm{H}_{3} \mathrm{PO}_{4}}$ into the DNAA-RNA fraction. Table 2 illustrates this comparison with a similar batch of cells labeled with ${ }^{32} \mathrm{P}_{-} \mathrm{H}_{3} \mathrm{PO}_{4}$ in the absence of hydroxylurea. 


\begin{tabular}{|ccc|}
\hline Table 2: & $\begin{array}{c}\text { Synthesis of DNAA-RNA and DNA in I-cells } \\
\text { grown in the presence of hydroxylurea }\end{array}$ \\
\hline \multicolumn{1}{|c|}{\begin{tabular}{l} 
Culture \\
\hline
\end{tabular}} & $32 \mathrm{P}$ in DNA & $32 \mathrm{P}$ in DNAA-RNA \\
\hline $\begin{array}{l}\text { cells grown in presence } \\
\text { of } 0.5 \mathrm{mM} \text { hydroxylurea } \\
\begin{array}{l}\text { cells grown in absence } \\
\text { of hydroxylurea }\end{array}\end{array}$ & $15.5 \times 10^{4} \mathrm{CPM}$ & $3.9 \times 10^{5} \mathrm{CPM}$ \\
\hline
\end{tabular}

These levels of hydroxylurea specifically inhibit DNA synthesis with little effect on RNA and protein synthesis. 27 The lack of a strong reduction in the synthesis of DNAA-RNA in the presence of $0.5 \mathrm{mM}$ hydroxylurea argues against (but clearly does not rule out) the involvement of this RNA in DNA synthesis in vivo.

What is the mode of attachment of the DNAA-RNA to the DNA? One obvious possibility is a "classical" hybrid between one strand of the DNA and a single strand RNA. The properties of such structures have been well characterized by their elution from hydroxylapatite columns in phosphate buffers, 28 and at high temperatures.29 A preparation of $100 \mu \mathrm{g}$ of ${ }^{32} \mathrm{P}$ labeled DNA ( $10^{7}$ CPM) containing DNAA-RNA was isolated from a $\mathrm{Cs}_{2} \mathrm{SO}_{4}$ gradient as described in Figure 1. The pooled DNA peak was passed over a $2.5 \mathrm{~cm} \times 50 \mathrm{~cm}$ high Sephadex G-100 column equilibrated with $0.3 \mathrm{M} \mathrm{NaCl}, 0.06 \mathrm{M} \mathrm{Pi}$ buffer. The DNA was collected in the void volume. The DNA was sheared by three passes through a 28 gauge needle. 21 The sheared DNA was then passed over a $1 \mathrm{~cm} \times 2 \mathrm{~cm}$ high hydroxylapatite column at $60^{\circ} \mathrm{C}$. The column was washed with $0.1 \mathrm{M} \mathrm{NaCl}, 0.06$ M Pi, 0.06\% SDS. Any single strand DNA or RNA was eluted from the column with $0.12 \mathrm{M} \mathrm{Pi}, 0.06 \% \mathrm{SDS}$ at $60^{\circ} \mathrm{C}$. Double stranded nucleic acids were eluted with $0.4 \mathrm{M} \mathrm{Pi} 0.06 \% \mathrm{SDS}$ at $60^{\circ} \mathrm{C}$. The eluted material from the column was dialyzed overnight against $1 \times$ SSC. The content of DNA and RNA in each fraction was then determined by treatment with $0.3 \mathrm{M} \mathrm{NaOH}$ as described above. From Figure 6a it is apparent that the DNAA-RNA elutes from the column in 
$0.4 \mathrm{M} \mathrm{Pi}$, consistent with this RNA being, or being part of, a double stranded nucleic acid structure.
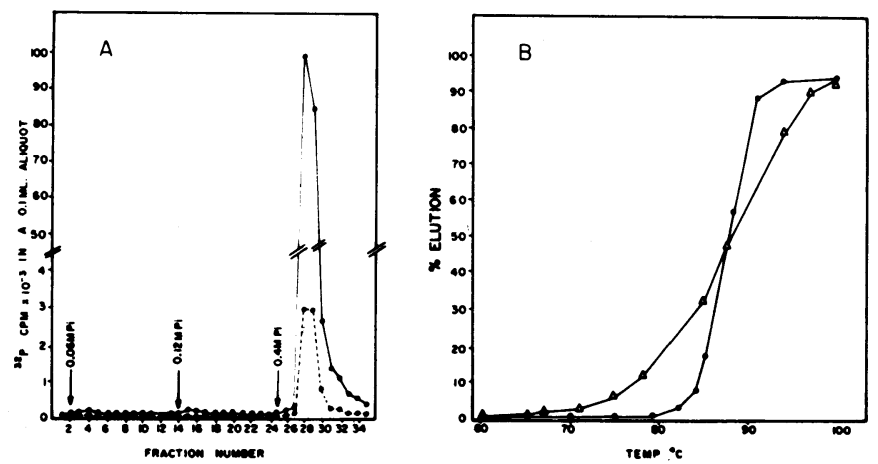

Fig. 6a: Elution of 32P labeled DNA ( - $\longrightarrow$ ) and DNAA-RNA (0- - -0) from a hydroxylapatite column with $0.12 \mathrm{M} \mathrm{Pi}$ and $0.4 \mathrm{M} \mathrm{Pi}$ at $60^{\circ} \mathrm{C}$.

b: Elution of $32 \mathrm{P}$ labeled DNA $(\bullet-\bullet)$ and DNAA-RNA $(\Delta-\Delta$ ) from hydroxylapatite with $0.12 \mathrm{M} \mathrm{Pi}$ and increasing column temperature.

We have also looked at the melting properties of the DNAA-RNA. A similar preparation of $32 \mathrm{P}$ labeled DNA containing DNAA-RNA was loaded on to a hydroxylapatite column as described above. The column temperature was then raised stepwise, the single stranded nucleic acids being eluted with $0.12 \mathrm{M}$ $\mathrm{Pi}$. It can be seen from Figure $6 \mathrm{~b}$ that the $\mathrm{Tm}$ of DNAA-RNA $\left(87.5^{\circ} \mathrm{C}\right)$ under these conditions is similar to that of DNA. However, the melting range is quite broad indicating some base mispairing for species melting of at lower temperatiures. About 20\% of the DNAA-RNA appears to melt off at temperatures greater than $94^{\circ} \mathrm{C}$. At this temperature most of the DNA has been eluted from the column. The nature of these RNA components is not clear at present. They may be species of high GC content or of complex secondary structure. The action of RNase $A(5 \mu \mathrm{g} / \mathrm{ml})$ and RNase $\mathrm{Tl}(5$ units/ml) on the DNAARNA fraction as it is associated with the DNA is seen in Table 3 . In this 
experiment, aliquots of the DNA + DNAA-RNA obtained from a $\mathrm{Cs}_{2} \mathrm{SO}_{4}$ gradient (DNA concentration $\sim 10 \mu \mathrm{g} / \mathrm{ml}$ ) described above is treated with ribonuclease for increasing lengths of time at $37^{\circ} \mathrm{C}$. In $2 \mathrm{mM}$ Tris- $\mathrm{HCl} \mathrm{pH} 7.6$ only about $13 \%$ of the RNA is resistant to RNase A + Tl after 30 minutes. In the presence of high salt, $0.4 \mathrm{M} \mathrm{NaCl}$, this resistance is increased to about $34 \%$. By contrast total I-cell ${ }^{32} \mathrm{P}$ labeled cytoplasmic RNA ( $5 \mu \mathrm{g} / \mathrm{ml}$ ) was rapidly hydrolyzed in either of the above conditions.

\begin{tabular}{|c|c|c|c|c|}
\hline \multicolumn{5}{|c|}{ Table 3: Action of RNase on DNAA-RNA } \\
\hline \multirow[b]{2}{*}{ Conditions } & \multirow[b]{2}{*}{ Enzyme } & \multicolumn{3}{|c|}{$\%$ of RNA Hydrolyzed } \\
\hline & & 10 mins. & 20 mins. & 30 mins. \\
\hline DNAA-RNA in $2 \mathrm{mM}$ Tris & RNase $A+T I$ & 79.9 & 83.1 & 86.3 \\
\hline DNAA-RNA in $0.4 \mathrm{M} \mathrm{NaCl}$ & RNase $A+T I$ & 28.9 & 50.4 & 66.0 \\
\hline CYT. RNA in $0.4 \mathrm{M} \mathrm{NaCl}$ & RNase A + Tl & 70.3 & 95.5 & 97.0 \\
\hline DNAA-RNA in $50 \mathrm{mM}$ Tris & RNase H & 0.0 & 0.1 & 0.1 \\
\hline DNAA-RNA in $0.4 \mathrm{M} \mathrm{NaCl}$ & RNase $\mathrm{H}$ & 0.0 & 0.0 & 0.2 \\
\hline poly dT.rA in $0.4 \mathrm{M} \mathrm{NaCl}$ & RNase $\mathrm{H}$ & 23.8 & 42.7 & 60.0 \\
\hline
\end{tabular}

RNA hydrolysis was assayed as 32P CPM, not bound to a $0.42 \mu$ Millipore filter in the presence of $10 \% \mathrm{TCA}$ and $10 \mu \mathrm{g} / \mathrm{ml} \mathrm{BSA}$.

The rather high sensitivity to RNase A +TI of the DNAA-RNA fraction in the presence of high salt would appear to argue against all of this RNA being hybridized to the DNA in the form of a double strand DNA-RNA hybrid structure since such structures are quite resistant to RNase A + TI under the above conditions. 30

The DNAA-RNA fraction is completely resistant to RNase $\mathrm{H}$ in either low or high salt conditions. The assay was carried out using the conditions described by Stavrianopoulos and Chargaff. 31 In the same reaction mixture 10 nmoles of $3_{\mathrm{H}}$ labeled poly $(\mathrm{dT}) \cdot \operatorname{poly}(\mathrm{rA})$ was $60 \%$ hydrolyzed by $20 \mathrm{ng}$ of RNase $\mathrm{H}$ after incubation for 30 minutes at $37^{\circ} \mathrm{C}$.

RNase $H$ has been shown to be specific for the cleavage of the RNA moiety of a double stranded DNA-RNA hybrid. 30 The apparent resistance of 
the DNAA-RNA fraction to hydrolysis by RNase H would suggest that this RNA is not attached to the DNA via a double stranded DNA-RNA hybrid. DISCUSSION

Almost all the chromatin RNA fractions (including "chromosomal RNA") 5 isolated to date can be dissociated from the DNA by solutions of high ionic strength.11,18 While the nature of their attachment to the chromatin structure is unclear, they are probably not in the form of a DNA-RNA hybrid structure, since such structures are not dissociated by high salt. In this paper we report our preliminary observations with a chromatin RNA fraction that is not dissociated from the DNA by high salt concentrations. Unfortunately, the exact nature of attachment of the DNAA-RNA to the DNA is unclear.

At this stage we cannot completely rule out the possibility that the DNAA-RNA is a form of nascent growing RNA chains produced by RNA polymerase immediately before the chromatin was isolated. It is difficult to distinguish this possibility from a case where specific fragments of the newly transcribed HnRNA reattach in a transient manner with chromatin. Present data with both procaryotic 35,36 and eucaryotic 37 systems do not indicate that RNA chains transcribed from DNA have the unique properties of the DNAARNA fraction. We have recently isolated another RNA fraction from chromatin which we believe to be nascent growing RNA chains. 42 The properties of this RNA are quite different to that of the DNAA-RNA fraction. For example, dif-

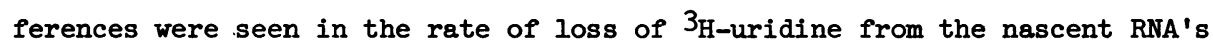
compared with the DNAA-RNA fraction after pulse chase type experiments.10

DNAA-RNA does not appear to be linked to the DNA via a protein moiety, nor does it appear to be covalently linked to a DNA strand. This RNA melts off a hydroxylapatite column at high temperature $\left(87.5^{\circ} \mathrm{C}\right)$. It is of low molecular weight $(24.5 \mathrm{~S})$ and can be separated from the DNA on a nitrocellulose column. The RNA as it is associated with the DNA, is unaffected by RNase $\mathrm{H}$, and is $70 \%$ digested by RNase $\mathrm{A}+\mathrm{Tl}$ in $0.4 \mathrm{M} \mathrm{NaCl}$. 
There are two hypothesis we are presently exploring as possible explanations for the above data. In one hypothesis stretches of purine sequences in the double helical DNA accomodate short pyrimidine-containing sequences of the DNAA-RNA in the deep groove of the helix.37 This is accomplished via an alternate base-pairing configuration, one involving hydrogen bonding with the imidazole nitrogen, $N-7$, of adenine and guanine. Such triple stranded structures are known for synthetic polynucleotides. $38,40,41$ They are quite stable. The RNA moiety is slowly hydrolyzed by RNase $A$ in the triplex $\mathrm{dT}_{\mathrm{n}}$. $\mathrm{dA}_{\mathrm{n}} \cdot r \mathrm{U}_{\mathrm{n}} \cdot 38$ Because the base composition of DNAA-RNA contains purines as well as pyrimidines it is necessary to assume that only part of the RNA is associated with the DNA in such a triple stranded complex, the rest of the RNA being unattached.

An alternative hypothesis we could suggest is that the DNAA-RNA may itself be a partial double stranded molecule (perhaps a hairpin loop in HnRNA) and this structure is associated with the DNA in the form of a four stranded structure somewhat along the lines of a structure proposed for 4 stranded DNA's and RNA's.8,9,39 We have clearly presented little evidence for this structure so far, the resistance of the DNAA-RNA in its association with DNA to RNase $\mathrm{H}$ and the high Tm of DNAA-RNA on hydroxylapatite being the basis of this suggestion. Again it is necessary to assume that only part of the RNA is associated with the DNA as a four stranded structure since the base composition does not appear to be symmetric and the RNA is partially hydrolyzed by RNase $\mathrm{A}+\mathrm{Tl}$ in $0.4 \mathrm{M} \mathrm{NaCl}$.

Both these hypotheses are now under investigation.

\section{ABBREVIATIONS}

DNAA-RNA, DNA associated RNA. TMED, N,N,N',N'-tetramethylethylenediamine. EDTA, disodium ethylenedinitrilotetra-acetic acid. DMSO, dimethylsulfoxide HEPES, N-2-hydroxyethylpiperzine-N'2-ethanesulfonic acid. HnRNA heterogenous nuclear RNA. PMSF, phenylmethylsulfonyl fluoride. RLI, Rat liver RNase 
inhibitor. SSC, standard saline citrate, $\mathrm{Pi}, \mathrm{Na}_{2} \mathrm{HPO}_{4}-\mathrm{NaH}_{2} \mathrm{PO}_{4}$ buffer $\mathrm{pH} 6.8$. ACKNOWLEDGEMENTS

The RNase $\mathrm{H}$ was a generous gift from Drs. J.S. Stavrianopoulos and E. Chargaff, Columbia University, New York. This work was supported by the Medical Research Council of Canada, grant number MA 2738. REFERENCES

1. Monahan, J.J. and Hall, R.H. (1974) Critical Reviews in Biochemistry, 2, 67-112, CRC Press, Cleveland, Ohio.

2. Britten, R.J. and Davidson, E.H. (1969) Science, 165, 349-357.

3. Frenster, J.H. and Herstein, P.R. (1973) New England J. of Med. 288, 1224-1229.

4. Kolodny, G.M. (1973) J. Cell Biol. 59, 175 (abs.)

5. Holmes, D.S., Mayfield, J.E., Sander, G. and Bonner, J. (1972) Science, 177, 849-855.

6. Artman, M. and Roth, J.S. (1971) J. Mol. Biol. 60, 291-301.

7. Scharpe, A. and Parijs, R.V. (1974) Biochim. Biophys. Acta, 353, 45-62.

8. McGavin, S. (1971) J. Mol. Biol. 55, 293-298.

9. Wu, T.T. (1969) Proc. Natn. Acad. Sci. U.S. 63, 400-405.

10. Monahan, J.J. and Hall, R.H. (1974) Can.J. Biochem. (in press).

11. Monahan, J.J. and Hall, R.H. (1974) Anal. Biochem. (in press).

12. Monahan, J.J. and Hall, R.H. (1973) Can. J. Biochem. 51, 903-912.

13. Boezi, J.A. and Armstrong, R. (1968) Methods in Enzymology, vol 12a, pp. 684-686, Academic Press, New York.

14. Burton, K. (1956) Biochem. J. 62, 315-323.

15. Webb, J.M. (1956) J. Biol. Chem. 221, 635-649.

16. Lowry, O.H., Rosebrough, N.J., Farr, A.L. and Randell, R.J. (1951) J. Biol. Chem. 193, 265-27.5.

17. Wnag, T.Y. (1968) Methods in Enzymology, vol. 12b, pp. 115-120, Academic Press, New York.

18. Weinberg, R. and Penman, S (1969) Biochim. Biophys. Acta, 190, 10-22.

19. Williams, A.E. and Vinograd, J. (1971) Biochim. Biophys. Acta, 228, 423-439.

20. Flam, W.G., Birnstiel, M.L. and Walker, P.M.B. (1972) Subcellular Components 2nd edn. (G.D. Birnie, ed), pp. 279-310, Butterworth, London.

21. Pyeritz, R.E., Schlegel, R.A. and Thomas, C.A., Jr. (1972) Biochim. Biophys. Acta, 272, 504-509.

22. Suginu, A., Hirose, S. and Ikazaki, R. (1972) Proc. Natn. Acad. Sci. U.S. 69 , 1863-1867.

23. Waguar, M.A. and Huberman, J.A. (1973) Biochem. Biophys. Res. Comm. 51, $174-180$.

24. Magnusson, G., Pigiet, V., Winnacker, E.L., Abrams, R. and Reichard, P. (1973) Proc. Natn. Acad. Sci. U.S. 70, $412-415$.

25. Berger, H., Jr. and Huang, R.C.C. (1972) Cell 2, 23-30.

26. Probst, H., Gentner, P.R., Hofstatter, T. and Jenke, S. (1974) Biochim. Biophys. Acta, 340, 361-373.

27. Young, C.W., Schochetman, S., Hodas, S. and Balis, M.E. (1967) Cancer Res. 27, 535-540.

28. Martinson, H.G. (1973) Biochemistry, 12, 2737-2746.

29. Bernardi, G. (1971) Methods in Enzymology, vol. 21, pp. 95-147, Academic Press, New York. 
30. Church, R.B. (1973) Molecular Techniques and Approaches in Developmental Biology, vol. 1, pp. 223-301, J. Wiley and Sons, Inc, New York.

31. Stavrianopoulos, J.G. and Chargaff, E. (1973) Proc. Natn. Acad. Sci. U.S. 70, 1959-1963.

32. Crick, F. (1971) Nature, 234, 25-27.

33. Jacob, R.J., Lebowitz, J. and Printz, M.P. (1974) Nucleic Acids Res. $1,549-558$.

34. Morgan, A.R. and Wells, R.D. (1968) J. Mol. Biol. 37, 63-80.

35. Warner, R.C., Samuels, H.H., Abbot, M.T. and Kraliow, J.W. (1963) Proc. Natn. Acad. Sci. U.S. 49, 533-538.

36. Bishop, J.0. (1969) Biochim. Biophys. Acta, 174-636-652.

37. Sethi, V.S. (1967) Progress in Biophysics and Molecular Biology, 23, pp. 67-96, Pregamon Press, Oxford.

38. Murray, N.L. and Morgan, A.R. (1972) Can. J. Biochem. 51, 436-449.

39. Thomas, B.R. (1973) Biochimie, 55, 1325-1339.

40. Stevens, C.L. and Felsenfeld, G. (1964) Biopolymers, 2, 293-314.

41. Miller, J.H. and Sobell, H.M. (1966) Proc. Natn. Acad. Sci. U.S. 55, 1201-1205.

42. Monahan, J.J. and Hall, R.H. (1974) Biochim. Biophys. Acta, (in press). 